\title{
RISK FACTORS FOR DIABETES TYPE 2 DEVELOPMENT. COMPARISON OF 6 MAJOR RISK FACTORS PREVALENCE BETWEEN NEWLY DIAGNOSED DIABETES PATIENTS FROM BIHOR COUNTY AND THE POPULATION WITH NORMAL GLUCOSE TOLERANCE FROM PREDATORR STUDY
}

\author{
Vesa Cosmin Mihai ${ }^{1,2}$, Popa Amorin Remus ${ }^{1,2}$ \\ ${ }^{1}$ Clinical County Emergency Hospital of Oradea, v_cosmin_15@yahoo.com \\ ${ }^{2}$ Faculty of Medicine and Pharmacy from Oradea, University of Oradea
}

\begin{abstract}
Diabetes mellitus represents a public health problem because of its growing prevalence and the enormous costs for its treatment and complications. There are numerous risk factors for diabetes mellitus development but the most important ones are the modifiable factors. In Bihor County the prevalence of obesity and sedentary behaviour in the population of newly diagnosed patients are increased compared to their prevalence in the population without diabetes. Promotion of healthy eating habits and increased physical effort are the most important measures to prevent diabetes mellitus type 2, which accounts for $90-95 \%$ of total diabetes cases. Public health programs that bring together physicians, nutritionists, teachers and target groups (children, young people, obese and overweight people) must be initiated in general population from an early age and maintained in order to promote the adherence to a healthy lifestyle.
\end{abstract}

Key word: risk factors for diabetes mellitus development

\section{Rezumat}

Diabetul zaharat reprezintă o problemă de sănătate publică din cauza prevaleței în creștere și costurilor enorme asociate tratatamentului și complicațiilor acestuia. Sunt numeroși factori de risc pentru apariția diabetului zaharat, dar cei mai importanți sunt cei modificabili. În județul Bihor, prevalența obezității și a sedentarismului sunt crescute comparativ cu prevalența acestora în populația fără diabet. Promovarea unei alimentații sănătoase și a activității fizice sunt cele mai importante măsuri de prevenție a diabetului zaharat de tip 2, care reprezintă 90-95\% din totalul de cazuri de diabet zaharat. Programele de sănătate publică în care comunică medici, nutriționiști, profesori și grupuri țintă (copii, tineri, persoane supraponderale, obeze) trebuie să fie inițiate de la vârste mici și menținute pentru a crește aderența la un stil de viață sănătos.

Cuvinte cheie: factori de risc pentru apariția diabetului zaharat. 


\section{INTERNAL}

\section{Original papers}

\section{Introduction}

Diabetes mellitus prevalence in 2017 was about 424 million cases, with the prediction that in 2045 there will be 628 million cases of diabetes mellitus worldwide. Healthcare cost regarding the treatment of diabetes mellitus and its complications are of approximately 727 billion dollars yearly ${ }^{(1)}$. This epidemic is highly preventable; the increase of diabetes cases worldwide appears as a consequence of an increase of type 2 diabetes cases and the most important risk factor for diabetes type 2 is obesity ${ }^{(2)}$.

\section{Material and methods}

Identification of the main risk factors, modifiable and non-modifiable, responsible for type 2 diabetes development was performed with the help provided by scientific data. In patients newly diagnosed with diabetes mellitus from Bihor County in 2016 and 2017 we identified the prevalence of obesity, hypertension, sedentary behaviour, dyslipidaemia, smoking, and family history of diabetes in order to compare the prevalence of these risk factors with their prevalence in the population with normal glucose tolerance from PREDATORR study.

\section{Results and discussions}

Obesity represents the most important modifiable risk factor for diabetes type 2 . This causative association maybe is best illustrated by the fact that in the United States of America 64 to $74 \%$ of diabetes cases would be prevented if the body mass index would be lower than $25 \mathrm{~kg} / \mathrm{m}^{2(2)}$.

Obesity is associated not only with high diabetes risk but also with high blood pressure and atherogenic dyslipidaemia ${ }^{(3)}$. Also obesity is associated with metabolic syndrome. Metabolic syndrome represents an association between obesity, hypertension, dyslipidaemia, glucose intolerance and dyslipidaemia $^{(4)}$. These factors are known to increase the cardiovascular risk, considering the fact that insulin resistance is the main element responsible for type 2 diabetes apparition ${ }^{(5)}$, and that insulin resistance is responsible for most components of metabolic syndrome the patients with type 2 diabetes have an increased risk of cardiovascular morbidity and mortality.

Hypertension is another risk factor for diabetes, although here the association is not causal $^{(6)}$. The explication is that both hypertension and diabetes type 2 are caused in great majority by obesity.

Education programs addressing diabetes prevention are necessary in Bihor County considering the increasing prevalence of diabetes with a doubling of the number of cases from 2000 to $2009^{(7)}$.

PREDATORR study performed between 2013 and 2014 in Romania identified a prevalence of $11.6 \%$ of diabetes mellitus ${ }^{(8)}$. Presence of 
different risk factors known to influence the development of diabetes mellitus was determined both in the diabetic population and in the population with normal glucose tolerance.

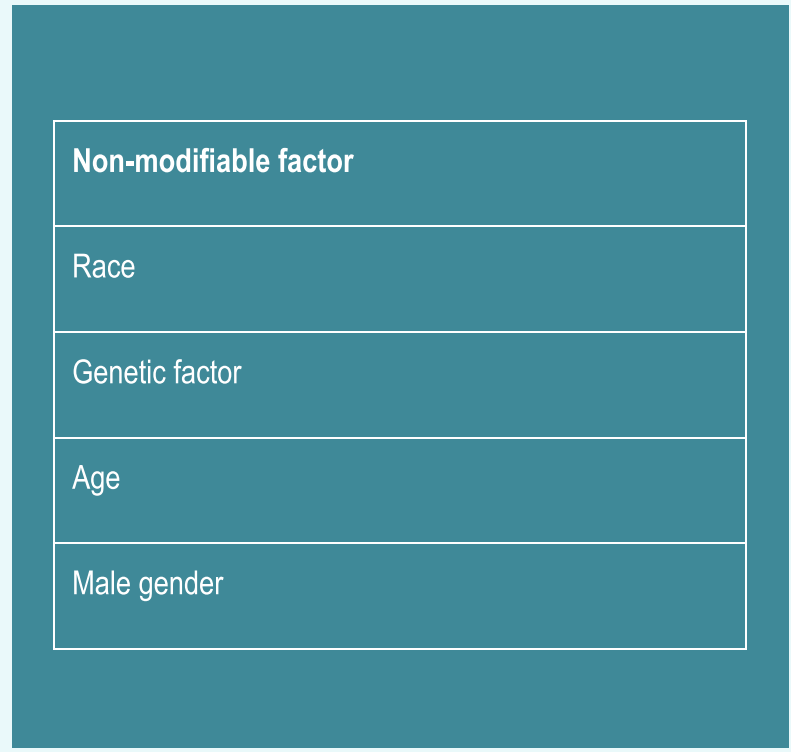

Table 1. Non-modifiable factor for type 2 diabetes development

The modifiable and non-modifiable risk factors for diabetes mellitus ${ }^{(9,10)}$ are enumerated in table 1 and table 2 . The impact of modifiable risk factors is significant and as a consequence prevention measures have been established in order to prevent diabetes type 2 . The most important measures include increasing physical effort to a minimum of 150 minutes of moderate intensity weekly and an adequate diet. Two types of diets can represent examples of healthy eating habits that reduce the risk of diabetes mellitus. Mediterranean diet consisting of an increased intake of fruits, nuts, fish, seafood, whole grains diminishes the risk of type 2 diabetes $(R R=0.87)$. $D A S H$ diet consisting of increased intake of fruits, cereals rich in fibres, dairy products with low fat content, reduces the risk of type 2 diabetes $(R R=0.81)$

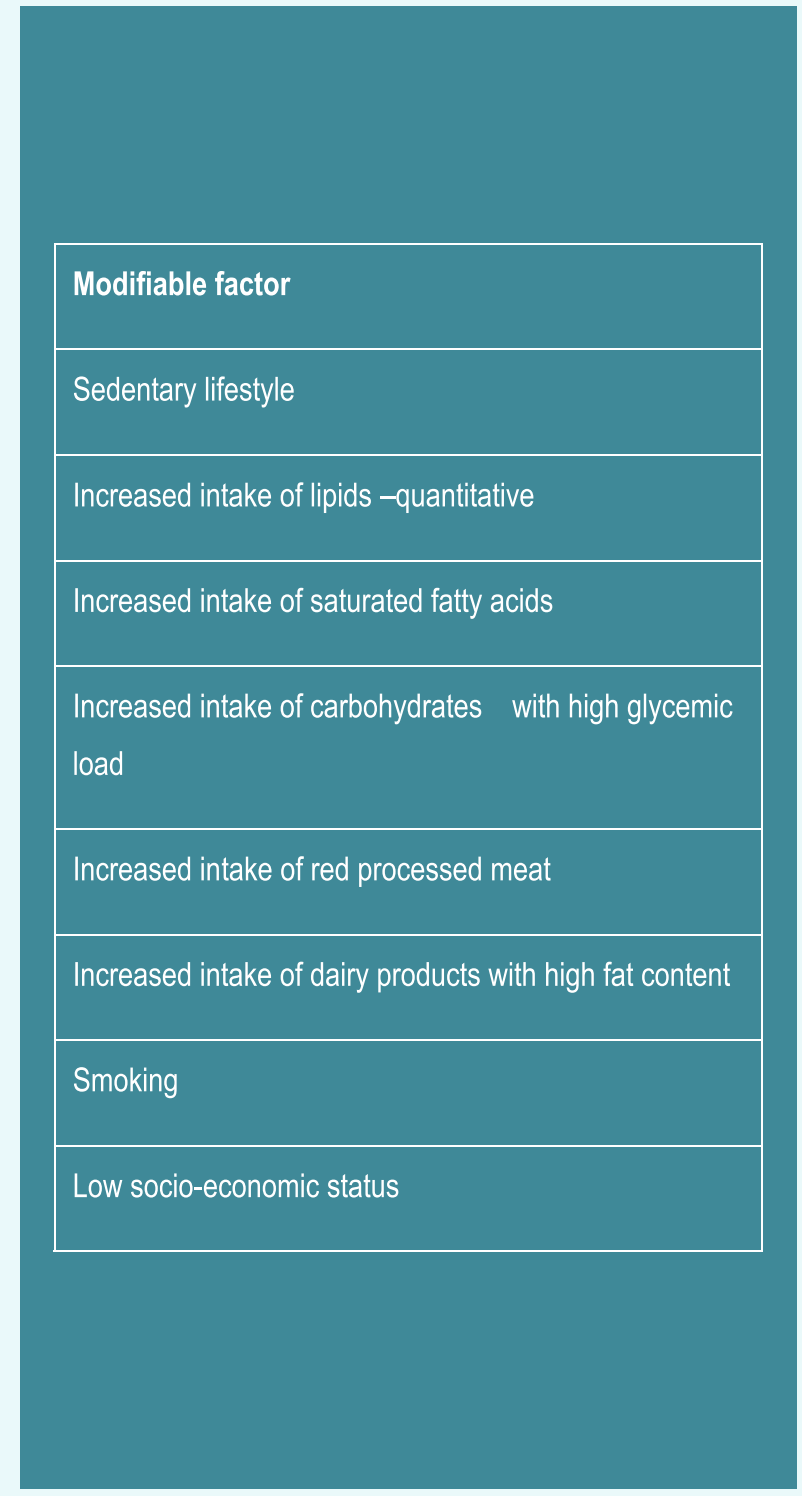

Table 2. Modifiable factor for type 2 diabetes development

We assessed the prevalence of 6 risk factors for type 2 diabetes in newly diagnosed diabetes mellitus patients from Bihor County in 2016 and 2017. 4 of the 6 risk factors were causative risk factors as identified by data from literature: obesity, sedetarism, familial history of diabetes mellitus, smoking and 2 were risk factors with predictive value: hypertension and dyslipidaemia, they do not cause directly diabetes mellitus but their presence means the existence of metabolic alterations, for example insulin resistance, 


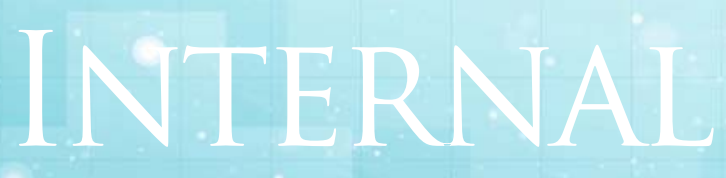

Original papers

that can lead to diabetes development. In 2016 among the newly diagnosed diabetes patients $52.01 \%$ were obese, $68.47 \%$ had hypertension, $71.20 \%$ had dyslipidaemia, $24.32 \%$ were smokers, $29.47 \%$ had a sedentary lifestyle, and $35.70 \%$ had familial history of diabetes mellitus.

Comparing the prevalence of these risk factors with their prevalence in the population with normal glucose tolerance from PREDATORR study, we observe that the strong predictor factors for diabetes type 2 development are obesity (OR=3.28), hypertension $(O R=1.31)$, sedentarism $(O R=1.62)$ and familial history of diabetes mellitus $(\mathrm{OR}=2.11)$.

In 2017 among the newly diagnosed diabetes patients $56.93 \%$ were obese, $72.83 \%$ had hypertension, $73.40 \%$ had dyslipidaemia, $22.80 \%$ were smokers, $31.52 \%$ had a sedentary lifestyle, and $34.20 \%$ had familial history of diabetes mellitus. Comparing this prevalence of these risk factors with their prevalence in the population with normal glucose tolerance from PREDATORR study, we observe that the strong predictor factors for diabetes type 2 development are obesity $(O R=4.00)$, hypertension $(O R=1.62)$, sedentarism $(O R=1.92)$ and familial history of diabetes mellitus (OR=1.98).

The high prevalence of obesity and sedentarism in the patients with newly diagnosed diabetes mellitus, and the great impact of obesity and sedentarism on the risk of developing type 2 diabetes raises the need for public health programs focused on educating population from Bihor County about the lifestyle modification necessary to prevent diabetes development. The main recommendation would be to increase physical activity and to promote healthy eating habits with high intake of fruits, vegetables, whole grains, fish similarly to Mediterranean diet and DASH diet. Young people from our county have little information about risk factors for health ${ }^{(11)}$, education for health (EFH) and health promotion (HP) are mandatory for the prevention diabetes, because type 2 diabetes, as data from literature demonstrates, is a preventable disease. The successful results of other health-programs regarding population education ${ }^{(12)}$ or promoting physicians communication ${ }^{(13)}$ active in Bihor county, gives us the hope that by gathering together diabetes physicians, primary care physicians teachers and pupils the understanding of the main principles for preventing diabetes and their application in real life will increase from early ages.

\section{Conclusions}

In 2016 and in 2017 obesity appears to be the most important risk factor for diabetes type 2 development in Bihor County. It is followed by 


\begin{tabular}{|l|c|c|c|c|}
\hline Risk factor & $\begin{array}{r}\text { Bihor patients } \\
\text { with newly } \\
\text { diagnosed } \\
\text { diabetes in } \\
\text { 2016(n=3451) }\end{array}$ & $\begin{array}{c}\text { PREDATORR } \\
\text { population with NTG } \\
\text { (n=1953) }\end{array}$ & OR diabetes & p-value \\
\hline Obesity & $52.01 \%$ & $24.80 \%$ & $3.28(\mathrm{Cl}: 2.90-$ & $<0.01$ \\
\hline Hypertension & $68.47 \%$ & $62.30 \%$ & 1.31 (Cl:1.17- \\
$1.47)$ & $<0.01$ \\
\hline Dyslipidaemia & $71.20 \%$ & $76.40 \%$ & $0.7(\mathrm{Cl}: 0.67-0.87)$ & $<0.01$ \\
\hline Smoking & $24.32 \%$ & $28.30 \%$ & $0.8(\mathrm{Cl}: 0.71-0.92)$ & $<0.01$ \\
\hline Familial history of & $35.70 \%$ & $20.80 \%$ & $1.62(\mathrm{Cl}: 1.42-$ & $<0.01$ \\
\hline diabetes mellitus & $29.47 \%$ & 2.11 (Cl:1.85- & $<0.01$ \\
\hline
\end{tabular}

Table 3. Risk factors for diabetes development in Bihor County in 2016. Comparison with the their prevalence in the population with normal glucose tolerance from PREDATORR study

\begin{tabular}{|l|c|c|c|c|}
\hline Risk factor & $\begin{array}{c}\text { Bihor patients } \\
\text { with newly- } \\
\text { diagnosed } \\
\text { diabetes in 2017 } \\
\text { (n=2705) }\end{array}$ & $\begin{array}{c}\text { PREDATORR } \\
\text { population with } \\
\text { NTG (n=1953) }\end{array}$ & OR diabetes & p-value \\
\hline Obesity & $56.93 \%$ & $24.80 \%$ & $4.00(\mathrm{Cl}: 3.52-4.55)$ & $<0.01$ \\
\hline Hypertension & $72.83 \%$ & $62.30 \%$ & $1.62(\mathrm{Cl}: 143-1.84)$ & $<0.01$ \\
\hline Dyslipidaemia & $73.40 \%$ & $76.40 \%$ & $0.85(\mathrm{Cl}: 0.74-0.97)$ & $<0.01$ \\
\hline Smoking & $22.80 \%$ & $28.30 \%$ & $0.74(\mathrm{Cl}: 0.65-0.85)$ & $<0.01$ \\
\hline Sedentarism & $31.52 \%$ & $20.50 \%$ & $1.92(\mathrm{Cl}: 1.67-2.20)$ & $<0.01$ \\
\hline
\end{tabular}

Table 4. Risk factors for diabetes development in Bihor County in 2017. Comparison with the their prevalence in the population with normal glucose tolerance from PREDATORR study 
positive familial history of diabetes and sedentary behaviour. Also hypertension is a good predictor of diabetes risk. Smoking did not represent a risk factor for diabetes and the presence of dyslipidaemia did not predict diabetes risk. These results demonstrate that lifestyle and familial inheritance play the most important role in type 2 diabetes development.

\section{References}

1. IDF DIABETES ATLAS - 8TH EDITION

2. WHO. Obesity: preventing and managing the global epidemic. Report of a WHO consultation. World Health Organ Tech Rep Ser 2000; 894:i-xii, 1-253.

3. Zalesin K.C., Franklin B.A., Miller W.M., Peterson E.D., McCullough P.A. Impact of obesity on cardiovascular disease. Med. Clin. North. Am. 2011;95:919-937

4. Keller KB, Lemberg L., Obesity and the metabolic syndrome., AmJ Crit Care. 2003 Mar;12(2):167-70.

5. Barbara B. Kahn Jeffrey S., FlierObesity and insulin resistance, J Clin Invest. 2000 Aug 15; 106(4): 473-481.

6. Min-Ju Kim, Hypertension is an independent risk factor for type 2 diabetes: the Korean genome and epidemiology study, Hypertens Res. 2015 Nov; 38(11): 783-789

7. Daina Lucia, Suciu Ramona, Chereji Anca, Daina Cristian, Analysis of morbidity from diabetes mellitus in
Bihor county, Analele Universităţii din Oradea, Fascicula Ecotoxicologie, Zootehnie şi Tehnologii de Industrie Alimntară, vol X/A, anul 10, Editura Universităţii din pag. 121-130

8. Mota M1, Popa SG1, Mota E2, Mitrea A, Prevalence of diabetes mellitus and prediabetes in the adult Romanian population: PREDATORR study, J Diabetes. 2016 May;8(3):336-44

9. Hubert Kolb and Stephan Martin, Environmental/ lifestyle factors in the pathogenesis and prevention of type 2 diabetes, BMC Medicine (2017) 15:131

10. NP Steyn, J Mann2 et.al., Diet, nutrition and the prevention of type 2 diabetes, Public Health Nutrition: 7(1A), 147-165

11. Daina Lucia Georgeta, Bonta Marinela, Chereji Anca, Pirte Adriana, Baldea Corina - Evaluating the activity aimed at promoting health and education for health in schools, Analele Universităţii din Oradea, Fascicula Ecotoxicologie, Zootehnie şi Tehnologii de Industrie Alimntară, vol X/B, anul 10, Editura Universităţii din Oradea, 2011, pag. 79-87

12. Daina Lucia Georgeta, Nicoleta Ramona Suciu, Daina Cristian Marius, Doctor-Patient Team Communication, CONVERGENT DISCOURSES. Exploring the Contexts of Communication, Arhipelag XXI Press, Tîrgu Mureș, 2016, 70-79

13. Zaha Dana Carmen, Daina Lucia, Evaluarea şi perfecţionarea comunicării organizaţionale în cadrul unităţii spitaliceşti, Acta Medica Transilvanica, anuI XVI, vol II Nr. 3, pp 38-39, 2011, Ed. Universitatii "Lucian Blaga" din Sibiu, ISSN-1453-1968 